\title{
Inappropriate renin secretion and abnormal cardiovascular reflexes in coarctation of the aorta
}

\author{
D J WARREN, R S SMITH, * R B NAIK \\ From the Hypertension Laboratory, Department of Renal Medicine, University of Southampton
}

SUMMARY The response of the renin-angiotensin system to high and low sodium diets, to standing, and to saralasin infusion was assessed before and after surgical correction of aortic coarctation in a 27-year-old man. The cardiovascular responses to tests of autonomic function were measured. The heart rate responses to the Valsalva manoeuvre and standing were abnormal before operation, and plasma renin levels were high and renin secretion responded poorly to changes in dietary sodium, to standing, and to saralasin. Renin responsiveness and cardiovascular reflexes returned to normal after operation. The results are consistent with the hypothesis that there is a high level of sympathetic efferent activity in coarctation of the aorta and that factors other than increased activity of the renin-angiotensin system may cause high blood pressure.

Two mechanisms have been proposed to explain high blood pressure in coarctation of the aorta. Before clearance methods for renal blood flow measurement and methods for the assay of renin became widely available, the primary mechanism for hypertension was thought to be mechanical obstruction caused by the aortic constriction, and the relatively high resistance offered by the collateral circulation. ${ }^{12}$ More recently, attention has focused on the reduction in renal blood flow, sometimes, but not invariably, ${ }^{34}$ seen in patients with coarctation, and the possibility that reduced perfusion of the kidneys may activate the reninangiotensin system. ${ }^{5}$ High levels of renin in peripheral blood have been found, and they have been noted to fall after surgical correction of the coarctation. ${ }^{6}$ This primarily renal mechanism of hypertension is based on the assumption that arterial pressure in the lower aorta is reduced. Several reports suggest that mean arterial pressure may be high below a coarctation, ${ }^{78}$ and any single hypothesis for hypertension should take this fact into account.

We describe studies of the renin-angiotensin system and cardiovascular responses to autonomic function tests before and after surgical correction of coarctation of the aorta in a young man. The results are consistent with a mechanism which does not necessarily require reduced renal perfusion ^Supported by a grant from the Wessex Regional Health Authority. pressure either to cause or to maintain hypertension in this condition.

\section{Case report and methods}

A 27-year-old man presented to his doctor with chest pain, and high blood pressure was noted. Subsequent physical examination showed typical features of aortic coarctation and a blood pressure of 180 to $240 / 70$ to $90 \mathrm{mmHg}$ in the arms. Blood pressure could not be measured by auscultation in the legs, where the femoral pulses were of very low volume. Left ventricular hypertrophy and strain were noted on electrocardiography. Cardiac catheterisation showed a systolic pressure gradient of $70 \mathrm{mmHg}$ across a typical post-subclavian coarctation.

Investigations were carried out six months before and nine months after operation. The patient was admitted to hospital and given a normal diet for two days, followed by a $20 \mathrm{mmol}$ sodium diet for five days and then a $20 \mathrm{mmol}$ sodium diet supplemented with $180 \mathrm{mmol} /$ day of sodium in the form of sodium chloride for a further four to five days. Dietary potassium was $60 \mathrm{mmol} /$ day throughout the study periods. Blood pressure and heart rate were measured and blood was taken daily for measurement of plasma renin activity at 08.00 hours with the patient fasting and supine, and then at midday when he had been up and active for at 
least three hours. Plasma renin activity was measured by radioimmunoassay of angiotensin I after three hours incubation at $\mathrm{pH} 5 \cdot 6$. The coefficient of variation for repeat measurements in aliquots from the same sample is 15 per cent. Urinary sodium excretion and body weight were recorded daily. While on a normal diet, saralasin (sar-1-ala-8-angiotensin), a competitive antagonist of angiotensin II, was infused intravenously for 20 minutes at $10 \mu \mathrm{g} / \mathrm{kg}$ body weight $/ \mathrm{min}$. Blood pressure was measured at two minute intervals using an Arteriosonde 1217 (Roche Instruments). Diastolic blood pressure was recorded as the fourth phase Korotkoff sound. Blood was taken for measurement of plasma renin activity immediately before the infusion, at the end of the infusion, and 30 minutes later.

The blood pressure and heart rate response to sustained handgrip and the heart rate response to the Valsalva manoeuvre and to standing were measured before and after operation. The change in heart rate and diastolic blood pressure in response to sustained handgrip at 30 per cent of maximum voluntary contraction was calculated. ${ }^{9}$ The ratio of heart rate during phases II and IV of the Valsalva manoeuvre (40 $\mathrm{mmHg}$ for 10 seconds) was calculated, ${ }^{10}$ as was the ratio of the $R R$ intervals at the 30th and 15th pulse beats after standing up. ${ }^{11}$

\section{Results}

Preoperative urinary sodium excretion fell from 85 to $25 \mathrm{mmol} / 24 \mathrm{~h}$ during five days on the low sodium diet, and body weight fell by $2 \cdot 1 \mathrm{~kg}$, confirming significant salt depletion. Plasma renin activity was more than twice the normal range of 1.0 to $2.0 \mu \mathrm{g} \mathrm{A} 1 / \mathrm{ml}$ per $\mathrm{h}$ on a normal diet and rose by 40 per cent to $5.9 \mu \mathrm{g} \mathrm{Al} / \mathrm{ml}$ per h on the low salt diet (Fig.). By the end of four days on the high sodium diet, urine sodium excretion had risen to 174 $\mathrm{mmol} / 24 \mathrm{~h}$ and supine plasma renin activity had fallen to $2.0 \mu \mathrm{g} \mathrm{Al} / \mathrm{ml}$ per $\mathrm{h}$. Mean supine plasma renin activity during two days on a normal diet was unchanged after activity (Table). Systolic and diastolic blood pressure was unaffected by saralasin infusion, the mean of 10 two-minute diastolic blood pressure readings during saralasin infusion being $4 \mathrm{~mm}$ less than the mean of 10 preinfusion values, and the plasma renin activity values did not rise (Table). The isometric exercise test before operation showed a normal rise in diastolic blood pressure and heart rate. The Valsalva ratio was 1.02 and significantly abnormal. ${ }^{9}$ The $30: 15 \mathrm{RR}$ ratio on standing was 1.00 , normal values being more than $1 \cdot 03 .{ }^{11}$

Mean standing plasma renin activity after operation was more than twice corresponding supine

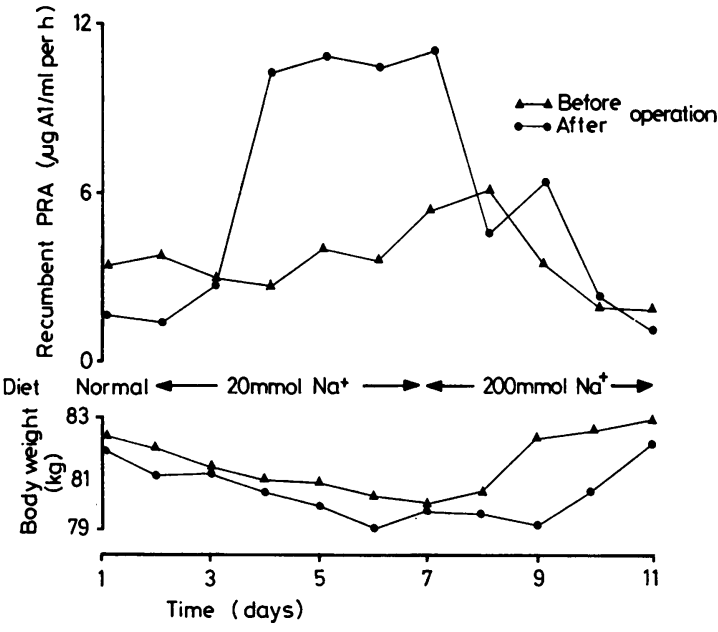

Fig. Changes in body weight and recumbent plasma renin activity (PRA) in response to dietary sodium changes before and after correction of coarctation of the aorta in a 27-year-old man.

values (Table). Urinary sodium excretion fell from 147 to $14 \mathrm{mmol} / 24$ hours on the low sodium diet and body weight fell by $1.5 \mathrm{~kg}$. Supine plasma renin activity was 50 per cent of preoperative values on a normal diet and rose eightfold by the end of the five day low sodium diet in contrast to the initial high levels and trivial rise which occurred before operation (Fig.). By the end of four days on a high sodium diet plasma renin activity had fallen below initial control values. Blood pressures and plasma renin activity were unchanged by saralasin infusion (Table). The postoperative isometric exercise test showed an initial blood pressure of $143 / 82 \mathrm{mmHg}$ and a heart rate of 75 beats/min, much lower than preoperative values. During sustained handgrip diastolic blood pressure and heart rate rose normally. The Valsalva ratio was normal $(1.37)$ as was the 30 : 15 ratio $(1 \cdot 25)$ (Table).

\section{Discussion}

These studies show large differences in the level of renin and the sensitivity of the renin angiotensin system when results before and after operation are compared. In addition there are obvious differences between blood pressure and heart rate responses to tests of cardiovascular reflexes.

\section{RENIN ANGIOTENSIN SYSTEM}

High blood pressure in coarctation of the aorta might be a consequence of mechanical obstruction 
offered by the constricted aortic segment and collateral vessels ${ }^{12}$ or caused by reduction in renal blood flow. ${ }^{3} 4$ It has been suggested that hypertension might result from stimulation of renin secretion as a result of low blood pressure or low pulse pressure in the distal aorta. ${ }^{5}$ Little evidence has been offered to show whether renin levels in peripheral blood respond normally to physiological stimuli. That renal ischaemia is a feature of coarctation of the aorta has been disputed and in some patients the mean arterial pressure in the distal segment has been shown to be high ${ }^{7}{ }^{8}$ so that no general hypothesis can be based on low renal perfusion pressure.

Plasma renin activity has been shown to be normal ${ }^{1213}$ and high $^{6}$ in coarctation of the aorta, and on the basis of normal unstimulated values on a normal diet it has been assumed that plasma renin activity plays no part in the maintenance of blood pressure in this disease. ${ }^{14}$ Plasma renin activity levels have been shown to increase in response to nitroprusside $^{15}$ and change in posture ${ }^{16}$ but the responsiveness of the renin angiotensin system to both stimulation and suppression tests before and after operation has not been examined. Normal resting levels of plasma renin activity do not support or refute a role for renin in the maintenance of high blood pressure, but failure of appropriate tests to change plasma renin activity has been noted in both essential hypertension ${ }^{17}$ and the hypertension of chronic renal failure. ${ }^{18}$

In normal subjects in our laboratory plasma renin activity rises two to threefold after three hours activity, and supine levels rise more than fourfold on a $20 \mathrm{mmol}$ sodium diet, falling to undetectable levels after three to four days on a diet containing more than $150 \mathrm{mmol}$ sodium daily. The results in our patient show high plasma renin activity levels on a normal sodium diet before operation. There was little response to change in posture, a poor response to a low sodium diet in spite of a large fall in body weight, and failure of suppression of plasma renin activity to the normally undetectable levels on a high salt diet in the face of a gain in weight to above resting values. All of these responses returned towards normal after operation, though plasma renin activity remained inappropriately high after the high salt diet. The high and relatively unresponsive levels of renin in peripheral blood may reflect a general increase in sympathetic efferent activity. This mechanism may increase plasma renin activity through activation of renal beta-adrenergic receptors mediating renin release and suggests another, possibly neurogenic, mechanism for hypertension. The saralasin infusion had no significant effect on diastolic blood pressure or plasma renin activity. Both negative features suggest that increased activity of the reninangiotensin system may not be the primary cause of high blood pressure in coarctation of the aorta.

\section{CARDIOVASCULAR REFLEXES}

The resting heart rate before operation was 110 beats/min and fell to 75 beats/min after operation. The sinus tachycardia before operation was associated with absence of typical reflex heart rate responses to both the Valsalva manoeuvre and to change in posture. Both reflex responses returned to normal after correction of the coarctation. Both have been shown to be mediated by the vagus nerve ${ }^{11} 19$ and the responses may be attenuated or absent when resting heart rate is high, suggestıng

Table Results of investigations in a patient with coarctation of the aorta

\begin{tabular}{|c|c|c|c|c|c|}
\hline & & \multicolumn{2}{|c|}{ Before operation } & \multicolumn{2}{|c|}{ After operation } \\
\hline \multicolumn{2}{|c|}{$\begin{array}{ll}\text { Plasma renin activity for two days on normal diet } \\
(\mu \mathrm{g} \mathrm{A} 1 / \mathrm{ml} \text { per } \mathrm{h}) & \text { Supine } \\
& \text { Standing }\end{array}$} & $\begin{array}{l}\text { Day } 1 \\
3 \cdot 69 \\
4 \cdot 60\end{array}$ & $\begin{array}{l}\text { Day } 2 \\
3 \cdot 81 \\
2 \cdot 30\end{array}$ & $\begin{array}{l}\text { Day } 1 \\
1 \cdot 74 \\
3 \cdot 70\end{array}$ & $\begin{array}{l}\text { Day } 2 \\
1 \cdot 68 \\
5 \cdot 20\end{array}$ \\
\hline \multicolumn{6}{|c|}{ Saralasin infusion } \\
\hline Blood pressure (mmHg) & $\begin{array}{l}\text { Before infusion } \\
\text { At end of infusion } \\
30 \text { min after infusion }\end{array}$ & \multicolumn{2}{|c|}{$\begin{array}{l}172 / 98 \\
160 / 102 \\
160 / 86\end{array}$} & \multicolumn{2}{|c|}{$\begin{array}{l}138 / 82 \\
134 / 82\end{array}$} \\
\hline Plasma renin activity ( $\mu \mathrm{g} \mathrm{Al} / \mathrm{ml}$ per $\mathrm{h}$ ) & $\begin{array}{l}\text { Before infusion } \\
\text { At end of infusion } \\
30 \text { min after infusion }\end{array}$ & & & & \\
\hline \multicolumn{6}{|l|}{$\begin{array}{l}\text { Cardiovascular reflexes } \\
\text { Handgrip test }\end{array}$} \\
\hline $\begin{array}{l}\text { Blood pressure before handgrip (mean of } 3 \text { values) }(\mathrm{mmHg}) \\
\text { Rise in diastolic blood pressure ( } \mathrm{mmHg} \text { ) }\end{array}$ & alues) (mmHg) & \multicolumn{2}{|c|}{27} & & \\
\hline $\begin{array}{l}\text { Valsalva ratio } \\
\text { Heart rate response to standing }\end{array}$ & & \multicolumn{2}{|c|}{1.02} & \multicolumn{2}{|c|}{$1 \cdot 37$} \\
\hline $30: 15$ ratio & & \multicolumn{2}{|c|}{1.00} & \multicolumn{2}{|c|}{$12 \cdot 5$} \\
\hline
\end{tabular}


reduced parasympathetic tone. The absent responses in coarctation of the aorta are consistent with high resting heart rate before operation and suggest a high level of efferent sympathetic activity. The heart rate and blood pressure response to sustained handgrip was normal before and after operation, which reflects the view that this response depends primarily on sympathetic efferent nervous activity.

These studies of the renin-angiotensin system and cardiovascular reflex responses support the hypothesis that the high levels of plasma renin activity and their relative unresponsiveness to physiological stimuli reflect a high level of efferent sympathetic activity in coarctation of the aorta. This mechanism may override the haemodynamic effects of posture ${ }^{20}$ and change in dietary sodium intake on plasma renin activity. This hypothesis does not suggest a primary role for the reninangiotensin system in the pathogenesis or maintenance of high blood pressure but is consistent with the observation that high mean blood pressure is seen in the lower aortic segment ${ }^{78}$ in some patients.

We are grateful to Eaton-Norwich Laboratories for supplies of saralasin.

\section{References}

1 Blumgart HL, Lawrence JS, Ernstene AC. The dynamics of the circulation in coarctation (stenosis of the isthmus) of the aorta of the adult type. Arch Intern Med 1931 ; 47: 806-23.

2 Brotchner RJ. Etiology of hypertension resulting from coarctation of the aorta. Arch Pathol 1939; 28: 676-96.

3 Friedman MA, Selzer A, Rosenblum H. The renal flow in coarctation of the aorta. $\mathcal{F}$ Clin Invest 1941; 20: $107-11$

4 Werkö L, Ek J, Bucht H, Karnell J. Cardiac output, blood pressures and renal dynamics in coarctation of the aorta. Scand $f$ Clin Lab Invest 1956; 8: 193-200.

5 Kohlstaedt KG, Page IH. Liberation of renin by perfusion of kidneys following reduction of pulse pressure. f Exp Med 1940; 72: 201-16.

6 Markiewicz A, Wojczuk D, Kokot F, Cicha A. Plasma renin activity in coarctation of aorta before and after surgery. Br Heart f 1975; 37: 721-5.
7 Steele JM. Evidence for general distribution of peripheral resistance in coarctation of the aorta: report of three cases. $\mathcal{F}$ Clin Invest 1941 ; 20: 473-80.

8 Harris JS, Sealy WC, DeMaria W. Hypertension and renal dynamics in aortic coarctation. $\mathrm{Am} \mathcal{f} \mathrm{Med}$ 1950; 9: 734-46.

9 Ewing DJ, Campbell IW, Burt AA, Clarke BF. Vascular reflexes in diabetic autonomic neuropathy. Lancet 1973; ii: 1354-6.

10 Levin AB. A simple test of cardiac function based upon the heart rate changes induced by the Valsalva maneuver. Am F Cardiol 1966; 18: 90-99.

11 Ewing DJ, Campbell IW, Murray A, Neilson JMM, Clarke BF. Immediate heart rate response to standing: simple test for autonomic neuropathy in diabetes. $\mathrm{Br} \mathrm{Med} \mathcal{F}$ 1978; i: 145-7.

12 Amsterdam EA, Albers WH, Christlieb AR, Morgan CL, Nadas AS, Hickler RB. Plasma renin activity in children with coarctation of the aorta. Am f Cardiol 1969; 23: 396-9.

13 Brown JJ, Davies DL, Lever AF, Robertson JIS. Plasma renin concentration in human hypertension II: Renin in relation to aetiology. $\mathrm{Br}$ Med $\mathcal{F}$ 1965; iv: $1215-9$.

14 Strong WB, Botti RE, Silbert DR, Liebman J. Peripheral and renal vein plasma renin activity in coarctation of the aorta. Pediatrics 1970; 45: 254-9.

15 Pickens PT. Relation of plasma renin to blood pressure in a patient with coarctation. Br Heart $\mathrm{f}$ 1967; 29: 135-6.

16 Werning C, Schönbeck M, Weidmann $P$, et al. Plasma renin activity in patients with coarctation of the aorta. Circulation 1969; 40: 731-7.

17 Padfield PL, Allison MEM, Brown JJ, et al. Effect of intravenous frusemide on plasma renin concentration: suppression of response in hypertension. Clin Sci Mol Med 1975; 49: 353-8.

18 Warren DJ, Ferris TF. Renin secretion in renal hypertension. Lancet 1970; i: 159-63.

19 Leon DF, Shaver JA, Leonard JJ. Reflex heart rate control in man. Am Heart f 1970; 80: 729-37.

20 McGivern D, Hardcastle A, Millar JGB, Warren DJ. Modification of the normal postural changes in plasma renin activity by the application of positive pressure to the legs. Clin Endocrinol (Oxf) 1979; 11: $105-9$.

Requests for reprints to Dr D J Warren, Hypertension Laboratory, Department of Renal Medicine, University of Southampton, St Mary's Hospital, Portsmouth PO3 6AD. 